\title{
Ocorrência da Mancha-Aquosa Causada por Acidovorax avenae subsp. citrulli, em Melão-Pepino no Brasil
}

\author{
Idjane S. de Oliveira ${ }^{1}$, Rui Sales Júnior ${ }^{2}$ \& Rosa L.R. Mariano ${ }^{1}$ \\ ${ }^{1}$ Universidade Federal Rural de Pernambuco, Departamento de Agronomia, Área de Fitossanidade, Dois Irmãos, CEP 52171-900, \\ Recife, PE, e-mail: idjaneoliveira@yahoo.com; ${ }^{2}$ Escola Superior de Agricultura de Mossoró, 59625-900, Mossoró, RN
}

(Aceito para publicação em 20/06/2003)

Autor para correspondência: Idjane Santana de Oliveira

\begin{abstract}
Occurrence of bacterial blotch caused by Acidovorax avenae subsp. citrulli in Cucumis melo var. cantalupensis in Brazil

Bacterial blotch, caused by Acidovorax avenae subsp. citrulli, is reported for the first time in Brazil, in 'melão-pepino' Cucumis

melo var. cantalupensis, a cucurbit grown, in the county of Baraúna, the main melon producer in the State of Rio Grande do Norte. To our knowledge this is also the first ocurrence of this disease, in this host, in the world.
\end{abstract}

A bactéria Acidovorax avenae subsp. citrulli (Schaad et al.) Willems et al. foi relatada inicialmente no Brasil infetando melancia [Citrullus lanatus (Thumb.) Matsum \& Nakai] (Robbs et al., Fitopatol. Bras. 16:XLVIII, 1991) e melão (Cucumis melo L.) (Robbs et al., Summa Phytopathol. 17:195, 1992), causando a mancha bacteriana dos frutos ou mancha-aquosa. Acredita-se que esta bactéria foi introduzida no Brasil através de sementes contaminadas (Assis et al., Fitopatol. Bras. 24:191, 1999). Esta doença tem atingido proporções epidêmicas, em plantios de melão nos estados do Rio Grande do Norte $(\mathrm{RN})$ e Ceará (CE), maiores produtores do Nordeste e do Brasil, causando freqüentemente 40 a $50 \%$ de perdas. O melão-pepino (Cucumis melo var. cantalupensis Naud.) é uma cucurbitácea cultivada no RN para consumo doméstico. Frutos de melão-pepino, com sintomas semelhantes aos da mancha-aquosa, provenientes do município de Baraúna, $\mathrm{RN}$, foram coletados em supermercado de Mossoró, RN. A superfície dos frutos apresentava pequenas lesões encharcadas, marrom escuras, circulares, medindo entre 5 e $10 \mathrm{~mm}$ de diâmetro (Figura 1A). Em alguns frutos, as lesões aprofundavam-se na polpa, estendendo-se até as sementes. O plantio das sementes extraídas de frutos infetados mostrou $48 \%$ de transmissão do patógeno. Colônias bacterianas, isoladas em meio de cultura NYDA, apresentaram características similares às de A. avenae subsp. citrulli, células Gram-negativas, circulares com bordos lisos, coloração creme, translúcidas, medindo cerca de $1 \mathrm{~mm}$ de diâmetro, após 24 h de crescimento. Plantas de melão-pepino, melão e melancia com 20 dias foram atomizadas com uma suspensão de células bacterianas com $3,4 \times 10^{7} \mathrm{ufc}^{\mathrm{ml}} \mathrm{ml}^{-1}$ e mantidas em câmara úmida durante 24 e $48 \mathrm{~h}$ antes e depois da inoculação em casa de vegetação. A bactéria foi reisolada em NYDA (Pusey \& Wilson, Plant Dis. 68:753-756, 1984) a partir de lesões típicas nas folhas, completando-se os postulados de Koch. Três isolados (MP1, MP2 e MP3) foram obtidos e identificados através dos testes bioquímicos (oxidase, catalase e redução de nitrato positivos; utilização de frutose e glicose como fonte de carbono, mas não de maltose, sacarose e lactose) (Saddler, Mycopathologia, 128:47-48, 1994), características morfológicas e fisiológicas [crescimento a 41 ${ }^{\circ} \mathrm{C}$ e hipersensibilidade em fumo (Nicotiana sp.) positivas] e por PCR utilizando os “primers" WFB1 e WFB2, espécie-específicos (Walcott \& Gitaitis, Plant Dis. 84:470-474. 2000) que amplificaram um produto com $\pm 300 \mathrm{pb}$ (Figura 1B). Os isolados encontram-se depositados na Coleção de Microrganismos do Laboratório de Fitobacteriologia, UFRPE. A ocorrência da mancha-aquosa em melãopepino evidencia mais um hospedeiro natural da A. avenae subsp. citrulli, o qual pode servir como fonte de inóculo para plantios de melão ou melancia, uma vez que as áreas cultivadas com cucurbitáceas são muito próximas dentro de uma mesma propriedade.

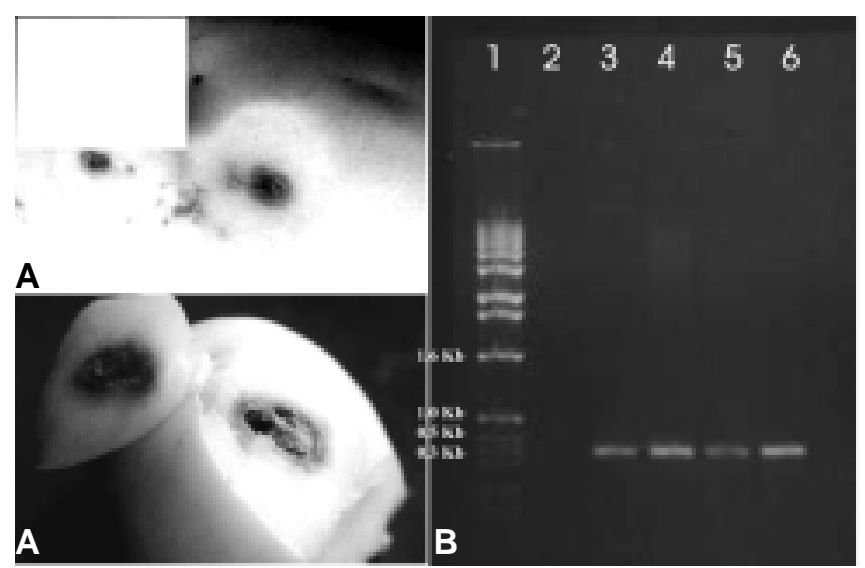

FIG. 1 - (A) Melão-pepino (Cucumis melo var. cantalupensis) apresentando os sintomas da mancha bacteriana na superfície e no interior do fruto. (B) - Gel de agarose a $1 \%$ mostrando o produto de amplificação por PCR (300 pb) dos isolados de Acidovorax avenae subsp. citrulli obtidos de melão-pepino (MP): 1 = Marcador de peso molecular, 2 = Controle negativo, 3 = isolado MP1, 4 = isolado MP2, 5 = isolado MP3 e 6 = Controle positivo, isolado AacR2 de melão (Cucumis melo). 